\title{
PERBEDAAN ASERTIVITAS REMAJA MINANG DITINJAU DARI POLA ASUH ORANG TUA
}

\author{
Suci Asysyura dan Gumi Langerya Rizal \\ Jurusan Psikologi, Universitas Negeri Padang, Sumatera Barat \\ Email: suciasysyura@yahoo.co.id, gumi.langerya@gmail.com
}

\begin{abstract}
Abstrak
Pada kondisi saat sekarang ini ditemukan banyak remaja yang sulit untuk asertif. Hal ini akan menimbulkan dampak yang cukup serius seperti, kecemasan sosial, ketakutan, dan kekhawatiran bahkan mengganggu kesehatan psikologis maupun fisik remaja. Salah satu faktor yang mempengaruhi asertivitas ialah pola asuh orang tua. Tujuan dari penelitian ini adalah untuk mengetahui perbedaan asertivitas remaja Minang ditinjau dari pola asuh orang tua. Metode penelitian yang dilakukan adalah kuantitatif komparatif. Subjek dalam penelitian ini adalah 153 orang remaja keturunan Minang yang berada di Sumatera Barat. Subjek dipilih menggunakan metode purposive sampling. Data dalam penelitian ini diolah dengan menggunakan uji Kruskall-Wallis dan uji post-hoct Mann-Whitney. Hasil penelitian ini menunjukkan bahwa ada perbedaan yang signifikan dalam asertivitas remaja ditinjau dari Pola Asuh Orang tua $(p=0,000, p<0,05)$, subjek dengan pola asuh authoritative ditemukan lebih asertif daripada subjek dengan pola asuh permissive, neglectful, dan authoritarian.
\end{abstract}

Kata kunci : asertivitas, pola asuh orang tua, remaja

\section{ASSERTIVINESS COMPARISON VIEWED FROM PARENTING STYLE AMONG ADOLESCENTS IN MINANG ASSESSED FROM}

\begin{abstract}
In the current condition, there are many adolescents who find it difficult to be assertive. This will have a serious impact such as social anxiety, fear, and anxiety and even interfere with the psychological and physical health of adolescents. One of the factors that influence assertiveness is parenting style. The purpose of this study was to determine the differences in Minang adolescence in terms of parenting style. The research method used is comparative quantitative. The subjects in this study were 153 adolescents of Minang in West Sumatra. Subjects were selected using the purposive sampling method. The data in this study were processed using the KruskallWallis test and the Mann-Whitney post-hoct test. The results of this study indicate that there are significant differences in adolescent assertiveness in terms of Parenting Parenting ( $p=0,000, p<0.05)$, subjects with authoritative parenting are found to be more assertive than subjects with permissive, neglectful, and authoritarian parenting.
\end{abstract}

Keywords: assertiveness, parenting style, adolescents

\section{Pendahuluan}

Masa remaja diartikan sebagai masa yang sangat penting dalam rentang kehidupan manusia, dimana transisi antara masa anak-anak dan masa dewasa mencakup perubahan biologis, kognitif, dan sosial-emosional (Santrock, 2014). Menurut Hurlock (1993) masa remaja dianggap sebagai suatu periode yang penting, karena perubahan yang dialami pada masa remaja akan memberikan dampak dan mempengaruhi perkembangan individu yang bersangkutan. Remaja terdiri dari seperlima populasi dunia (1,8 milliar), 85 \% dari populasi ini tinggal di negara berkembang (Eslami, Rabiei, Afazali, Hamidizadeh, \& Masoudi, 2016). Berdasarkan data dari BKKBN menyebutkan bahwa pada tahun 2016, penduduk remaja di Indonesia yang berusia 10 - 24 tahun berjumlah sebanyak 66,3 juta jiwa dari 
jumlah total penduduk sebesar 258,7 juta sehingga satu diantara empat penduduk ialah remaja (bkkbn.go.id).

Remaja merupakan pilar suatu bangsa, oleh karena itu remaja memiliki peran penting dalam berkontribusi untuk perkembangan sosial (Parray \& Kumar, 2017). Jadi, penting bagi remaja untuk bersikap asertif, karena bersikap asertif dapat membantu mereka dalam banyak hal. Ini membantu dalam meningkatkan kepercayaan diri, harga diri dan juga membantu mereka untuk mempertahankan hak mereka tanpa menjadi agresif dan melanggar hak orang lain (Parray \& Kumar, 2017). Selain itu, pada usia remaja individu kondusif untuk membangun visi, inisiatif, kualitas, ketekunan dan kemandirian yang merupakan prasyarat objektif untuk pengembangan asertivitas (Dagnew \& Asrat, 2017).

Asertivitas ialah perilaku yang melibatkan seseorang untuk dapat mengekspresikan diri secara langsung, tegas, positif, dan tindakan persisten untuk kesetaraan dalam hubungan antar pribadi (Alberti \& Emmons, 2017). Asertivitas memungkinkan untuk mengekspresikan kebutuhan dan perasaan dengan jujur dan nyaman, untuk membela diri tanpa kecemasan yang tidak semestinya, serta menggunakan hak-hak pribadi tanpa mengingkari hak-hak orang lain.

Pada kondisi saat ini ditemukan banyak remaja yang sulit untuk mengekspresikan diri secara efektif. Hal ini didukung oleh penelitian Parray dan Kumar (2016) yang menemukan bahwa terdapatnya asertivitas yang rendah di kalangan mahasiswa. Selanjutnya, penelitian Setiono dan Pramadi (dalam Pratiwi, 2015) menemukan bahwa permasalahan yang sering menjadi keluhan tenaga pengajar ialah kurangnya keberanian siswa untuk mengemukakan pendapat di dalam kelas, kurangnya keaktifan dan inisiatif baik di dalam kelas, maupun organisasi. Hasil penelitian menemukan bahwa meningkatnya perilaku seksual pranikah, perempuan yang menjadi korban seksual, dan remaja yang menjadi korban bullying memiliki permasalahan dengan asertivitas (Hosseini, Mirnasab, Salimy \& Zangiabadi, 2015; Zerubavel \& Messman, 2017; Karniyanti \& Lestari, 2018). Individu yang tidak asertif berfungsi secara pasif, bahkan cenderung untuk menjadi korban (Sudha, 2005). Rendahnya asertivitas memiliki hubungan positif yang tinggi dengan ketakutan, kekhawatiran, kecemasan sosial, dan berbagai agresi internal (Eslami, Rabiei, Afzali, Hamidizadeh \& Masoudi, 2016). Bahkan dapat melemahkan kemampuan dan potensi, penurunan bakat, bukan hanya membahayakan kesehatan psikologis tetapi juga fisik individu (Mohebi et al., 2012).

Rathus dan Nevid (1977) mengemukakan salah satu faktor yang mempengaruhi asertivitas ialah pola asuh orang tua. Dari banyak konteks perkembangan remaja, pola asuh memiliki peran penting dalam perkembangan diri individu (Steinberg \& Morris, 2001). Karena, pola asuh orang tua merupakan awal bentuk proses interaksi dengan lingkungan yang dipelajari oleh anak yang akan memberikan pengaruh pada kepribadian dan keterampilan seseorang. Orang tua dianggap sebagai pengaruh tunggal terbesar dalam hidup anak-anak mereka selama tahun-tahun awal (Shilling, 2007).

Asertivitas berkembang secara bertahap selama bertahun-tahun sebagai akibat jenis interaksi seorang anak dengan orang tuanya, pola asuh yang salah mengakibatkan tidak adanya kesempatan individu untuk mengembangkan perilaku asertif (Rathus \& Nevid, 1977). Hal ini diperkuat oleh Penelitian Harris dalam (Marini \& Andriani, 2005) yang menjelaskan bahwa kualitas asertif perilaku seseorang diperoleh dari pengalaman masa kanak-kanak, pengalaman berupa interaksi dengan orang tua melalui pola asuh yang ada dalam keluarga akan menentukan pola respons seseorang dalam menghadapi masalah di masa depan kelak. Shilling (2007) menjelaskan bahwa asertivitas ialah salah 
satu area pengaruh yang berasal dari orang tua terhadap anak, jika orang tua bersikap asertif maka anak-anak mereka akan cenderung asertif pula.

Beberapa temuan penelitian sebelumnya menyatakan bahwa pola asuh orang tua mempengaruhi asertivitas individu. Hal ini didukung oleh penelitian Abdulkarim, Zainul dan Mariyani (2014) yang menemukan bahwa pola asuh orang tua berpengaruh signifikan positif terhadap perilaku asertif. Selanjutnya, penelitian Marini dan Andriani (2005) menemukan bahwa terdapat perbedaan asertivitas yang signifikan antara pola asuh authoritarian, authoritative, permissive, dan uninvolved, asertivitas subjek dengan pola asuh authoritative lebih tinggi daripada subjek dengan pola asuh authoritarian, permissive, dan uninvolved. Selain itu, penelitian Alayi, Khamen, Ahmadigatab (2011) menemukan bahwa terdapat perbedaan antara asertivitas siswa dan pola asuh orang tua. Individu dengan pola asuh indulgent memiliki asertivitas yang lebih tinggi dibandingkan dengan individu pola asuh authoritarian

Sejalan dengan hal tersebut, faktor lain yang mempengaruhi asertivitas ialah budaya, nilai-nilai budaya itu sendiri tidak dapat dipisahkan dari perilaku asertif remaja (Lee \& Ciftci, 2014). Perbedaan perilaku asertif antara budaya dipengaruhi oleh nilai-nilai yang diadopsi oleh masing-masing individu yang nantinya mempengaruhi peran individu tersebut (Fajri, Nirwana \& Alizamar 2019). Misalnya etnis Minang dikenal dengan individu karakter berterus terang atas apa yang dipikirkan dan dirasakan, terbuka, serta cara berkomunikasi dengan suara yang lantang (Oktaria, Siregar, Kustanti, 2018). Orang Minangkabau cenderung untuk lebih berani, terbuka, dan demokratis (Navis dalam Suciati \& Agung, 2017; Firdaus, Lubis, Susanto, \& Soetarto, 2018). Namun, hal tersebut berbeda dengan fenomena dan hasil penelitian yang ditemukan oleh Andayani dan Mardianto (2015) yang menemukan bahwa asertivitas mahasiswa etnis Minang cenderung berada pada kategori rendah. Berdasarkan uraian latar yang telah dipaparkan diatas, peneliti tertarik untuk mengetahui perbedaan asertivitas remaja etnis Minang ditinjau dari pola asuh orang tua.

\section{Metode Penelitian}

Penelitian ini menggunakan pendekatan kuantitatif komparatif yang bertujuan untuk melihat perbedaan asertivitas jika dilihat dari pola asuh orang tua yaitu pola asuh authoritative, authoritarian, permissive, dan neglectful. Responden dalam penelitian ini adalah 153 orang remaja Minang yang berada di Sumatera Barat. Teknik pengambilan sampel dalam penelitian ini adalah sampling purposive, dengan beberapa kriteria seperti, berusia $12-22$ tahun, berasal dari Minang, dan responden tinggal bersama orang tua serta orang tua yang memegang peran dominan dalam pengasuhan.

Dalam penelitian ini menggunakan alat ukur skala asertivitas dan skala pola asuh orang tua. Skala asertivitas di desain oleh peneliti berdasarkan aspek-aspek dari Alberti dan Emmons (2017). Kemudian, skala pola asuh orang tua menggunakan alat ukur yang diadaptasi dari Handayani (2015) yang disusun berdasarkan jenis pola asuh orang tua yang dikemukakan oleh Baumrind (dalam Santrock, 2014).

Sebelum dilakukan penelitian, peneliti melakukan uji coba alat ukur skala asertivitas. Setelah dilakukan uji coba, diperoleh nilai koefisien realibilitas sebesar 0,852 , hal ini berarti alat ukur dapat dikatakan sangat reliabel. Reliabilitas dari keempat pola asuh dapat dikatakan memperoleh reliabilitas yang sangat baik, Authoritarian memiliki reliabilitas sebesar 0,997, authoritative sebesar 0,992, permissive indulgent sebesar 0,992 dan permissive neglectful sebesar 0,997 (Delavita, 2015). Kemudian, hasi analisis uji coba menunjukkan indeks daya beda aitem asertivitas dengan koefisien 
berkisar antara 0,23 hingga 0,617. Azwar (2012) menjelaskan bahwa apabila aitem yang lolos ternyata masih tidak mencukupi jumlah yang diinginkan, maka dapat dipertimbangkan diturunkan sedikit batas kriteria menjadi 0,20.

\section{Hasil Penelitian}

\section{Gambaran Umum Subjek Penelitian}

Adapun gambaran umum Subjek dalam penelitian ini dapat dilihat pada tabel 1 dan 2 berikut ini, Tabel 1. Gambaran Subjek Berdasarkan Jenis Kelamin

\begin{tabular}{lcc}
\hline Jenis Kelamin & Frekuensi & Presentase \\
\hline Laki-Laki & 50 & $32,68 \%$ \\
Perempuan & 103 & $67,32 \%$ \\
Total & $\mathbf{1 5 3}$ & $\mathbf{1 0 0 \%}$
\end{tabular}

Berdasarkan tabel 1 terlihat bahwa dari 153 subjek penelitian berdasarkan jenis kelamin terdapat 50 orang (32,68\%) subjek dengan jenis kelamin laki-laki dan 103 orang $(67,32 \%)$ dengan jenis kelamin perempuan.

Tabel 2. Gambaran Subjek Berdasarkan Usia

\begin{tabular}{|c|c|c|c|}
\hline No. & Usia Subjek & $\begin{array}{c}\text { Frekuensi } \\
\text { (F) }\end{array}$ & $\begin{array}{c}\text { Persentase } \\
\text { (\%) }\end{array}$ \\
\hline 1. & $12-15$ tahun & 30 & $19,6 \%$ \\
2. & $16-18$ tahun & 84 & $54,90 \%$ \\
3. & $19-22$ tahun & 39 & $26 \%$ \\
& Total & $\mathbf{1 5 3}$ orang & $\mathbf{1 0 0 \%}$ \\
\hline
\end{tabular}

Berdasarkan tabel 2 terlihat bahwa dari 153 subjek penelitian berdasarkan usia terdapat 30 orang $(19,6 \%)$ subjek yang berada pada rentang usia 12 - 15 tahun yang termasuk kategori remaja awal, 84 orang $(54,90 \%)$ berada pada rentang usia 16 - 18 tahun yang termasuk kategori remaja madya, dan 39 orang ( $26 \%$ ) berada pada rentang usia $19-22$ tahun yang termasuk kategori remaja akhir.

Tabel 3. Gambaran Kategorisasi Asertivitas Subjek

\begin{tabular}{|c|c|c|c|c|}
\hline Standar Deviasi & Skor & Kategorisasi & $\begin{array}{l}\text { Frekuensi } \\
\text { (F) }\end{array}$ & $\begin{array}{c}\text { Persentase } \\
\text { (\%) }\end{array}$ \\
\hline$X<(\mu-1,0 \sigma)$ & $x<52$ & Rendah & 11 & $7,2 \%$ \\
\hline $\begin{array}{c}(\mu-1,0 \sigma) \leq X< \\
(\mu+1,0 \sigma)\end{array}$ & $52 \leq X<104$ & Sedang & 110 & $71,8 \%$ \\
\hline$(\mu+1,0 \sigma) \leq X$ & $104 \leq X$ & Tinggi & 32 & $21 \%$ \\
\hline \multicolumn{3}{|c|}{ Jumlah } & 153 & $100 \%$ \\
\hline
\end{tabular}

Berdasarkan tabel 3 di atas, dapat dilihat bahwa yang memiliki asertivitas yang rendah sebanyak 11 orang $(7,2 \%), 110$ orang $(71,8 \%)$ memiliki asertivitas sedang, dan 32 orang ( $21 \%)$ yang memiliki asertivitas yang tinggi. Hal ini menunjukkan bahwa secara umum subjek dalam penelitian ini memiliki asertivitas yang sedang. 
Tabel 4. Gambaran Pola Asuh Orang tua Subjek

\begin{tabular}{|c|c|c|}
\hline Jenis Pola Asuh Orang Tua & Frekuensi (F) & Persentase (\%) \\
\hline Authoritarian & 30 & $19,6 \%$ \\
\hline Authoritative & 65 & $42,48 \%$ \\
\hline Permissive & 40 & $26,15 \%$ \\
\hline Neglectful & 18 & $11,8 \%$ \\
\hline Jumlah & $\mathbf{1 5 3}$ & $\mathbf{1 0 0 \%}$ \\
\hline
\end{tabular}

Berdasarkan keterangan pada tabel 4 diperoleh bahwa dari 153 subjek dalam penelitian ini terdapat 30 orang $(19,6 \%)$ subjek yang memiliki pola asuh authoritarian, 65 orang $(42,48 \%)$ subjek yang memiliki pola asuh authoritative, 40 orang $(26,15 \%)$ subjek yang memiliki pola asuh permissive indulgent, dan 18 orang subjek $(11,8 \%)$ yang memiliki pola asuh permissive neglectful.

\section{Analisis Data}

Tabel 5. Uji Asumsi Normalitas

\begin{tabular}{l|c|c|c|}
\hline \multicolumn{1}{|c|}{ Variabel Penelitian } & \multicolumn{3}{|c|}{ Kolmogorov-Smirnov } \\
\cline { 2 - 4 } & statistik & $\mathrm{df}$ & Sig. \\
\hline Authoritarian & 0,149 & 30 & 0,087 \\
Authoritative & 0,091 & 65 & 0,200 \\
Permissive indulgent & 0,085 & 40 & 0,200 \\
Permissive neglectful & 0,471 & 18 & 0,000 \\
\hline
\end{tabular}

Berdasarkan tabel 5 menunjukkan hasil yang diperoleh berupa nilai $p>0,05$ kecuali pada pola asuh permissive neglectful diperoleh nilai $p<0,05$ yang memiliki arti bahwa distribusi data tidak normal. Hasil keseluruhan dari uji normalitas ini yaitu data berdistribusi tidak normal. Oleh karena itu peneliti tidak dapat melanjutkan uji one way anova dikarenakan tidak memenuhi salah satu syarat uji one way anova yaitu data terdistribusi normal. Selanjutnya, dilakukan uji alternatif Kruskall-Wallis yang bersifat statistika non parametrik yang tidak harus memenuhi asumsi normalitas dan homogenitas dalam suatu data penelitian (Dahlan, 2011).

Uji Kruskall-Wallis ialah uji non parametrik yang merupakan uji alternatif untuk data kategorik/numerik dengan kelompok lebih dari 2 dan memiliki distribusi data yang tidak normal (Dahlan, 2011). Hasil dari uji Kruskall-Wallis disajikan pada tabel berikut: 
Tabel 6. Hasil Uji Kruskall-Wallis

\begin{tabular}{|l|c|}
\hline & Asertivitas \\
\hline Chi-Square & 55,866 \\
df & 3 \\
Asymp.Sig & 0,000 \\
\hline
\end{tabular}

Berdasarkan hasil analisis uji Kruskall-Wallis pada tabel 6 diperoleh nilai $p=0,000(p<0,05)$ yang menandakan $\mathrm{HO}$ ditolak dan $\mathrm{Ha}$ diterima. Hal ini menunjukkan bahwa terdapat perbedaan asertivitas remaja ditinjau dari pola asuh orang tua. Perbedaan asertivitas remaja ditinjau dari pola asuh orang tua dapat dilihat dari perolehan mean pada tabel 7.

Tabel 7. Mean Asertivitas Remaja ditinjau dari Pola Asuh Orang Tua

\begin{tabular}{|c|c|}
\hline Jenis gaya pengasuhan & Mean \\
\hline Authoritarian & 37,10 \\
\hline Authoritative & 104,73 \\
\hline Permissive & 73,13 \\
\hline Neglectful & 51,97 \\
\hline
\end{tabular}

Berdasarkan keterangan pada tabel 7 dapat diketahui bahwa asertivitas remaja dengan pola asuh authoritative memperoleh nilai mean yang paling tinggi yaitu 104,73 . Selanjutnya, remaja dengan pola asuh permissive memperoleh nilai mean 73,13 . Remaja dengan pola asuh neglectful memperoleh nilai mean 51,97. Kemudian, remaja dengan pola asuh authoritarian memperoleh nilai mean terendah yaitu 37,10 .

Tabel 8. Hasil Uji Perbandingan Asertivitas Berdasarkan Jenis Kelamin

\begin{tabular}{|l|c|}
\hline & Asertivitas \\
\hline $\begin{array}{l}\text { Asymp.Sig } \\
\text { (2-tailed) }\end{array}$ & 0,277 \\
\hline
\end{tabular}

Berdasarkan tabel 8 diatas diperoleh nilai $p=0,277(p>0,05)$ hal ini berarti menunjukkan bahwa tidak terdapat perbedaan asertivitas antara laki-laki dan perempuan pada remaja keturunan Minang.

\section{Pembahasan}

Berdasarkan hasil kategorisasi yang dilakukan dalam penelitian ini diketahui bahwa secara umum gambaran tingkat asertivitas remaja Minang di Sumatera Barat berada pada kategori sedang. Dimana mayoritas dari subjek dalam penelitian ini yaitu sekitar $71,8 \%$ berada pada kategori asertivitas sedang, $21 \%$ berada pada kategori asertivitas tinggi, dan 7,2 \% berada pada kategori asertivitas yang rendah. Hal ini menunjukkan bahwa mayoritas remaja Minang memiliki asertivitas yang cukup baik. Namun, masih diperlukan peningkatan asertivitas lagi agar remaja tetap konsisten dan tidak mudah terpengaruh oleh lingkungan yang kurang baik.

Hasil penelitian ini juga menunjukkan bahwa 42,48 \% subjek memiliki gaya pengasuhan authoritative, $26,15 \%$ dengan pola asuh permissive, $19,6 \%$ pola asuh authoritarian dan $11,8 \%$ dengan pola asuh neglectful. Hal ini menunjukkan bahwa mayoritas remaja Minang memiliki gaya pengasuhan authoritative. Hal ini sesuai dengan penelitian Fitrianto (2012) yang menunjukkan bahwa pola komunikasi yang diterapkan oleh keluarga Minang ialah pola komunikasi yang intens, dimana ada pemberian nasihat, teguran, tidak memperlihatkan figur yang berkuasa tetapi dengan memperlihatkan 
figur yang mengayomi, melindungi, dan mencintai anak. Pola komunikasi yang terjalin tidak hanya satu arah, namun dua arah yang mana orang tua tidak hanya memberikan keputusan sepihak kepada anak, orang tua juga memberikan peluang kepada anak untuk mengutarakan pendapatnya. Pola asuh di Minangkabau sangat disiplin dan tegas, tegas disini bukan melakukan kekerasan tetapi dalam mendidik anak jika melakukan kesalahan (Pratama, 2019). Mengacu kepada hasil penelitian Firdaus, Lubis, Susanto, dan Soetarto (2018) mengenai potret budaya Minang yang digambarkan bahwa kehidupan sehari-hari masyarakat Minang cenderung untuk lebih demokratis dan terbuka.

Berdasarkan hasil analisis menggunakan uji Kruskall-Wallis diperoleh hasil bahwa terdapat perbedaan asertivitas remaja Minang ditinjau dari pola asuh orang tua. Perbedaan rerata asertivitasnya dapat dilihat dari perolehan mean yang mana remaja dengan pola asuh authoritative memperoleh nilai mean asertivitas yang paling tinggi yaitu 104,73 . Hal ini sesuai dengan penelitian Marini dan Andriani (2005) yang menemukan bahwa terdapat perbedaan assertivitas yang signifikan antara pola asuh authoritarian, authoritative, permissive, dan uninvolved, asertivitas subjek dengan pola asuh authoritative lebih tinggi daripada subjek dengan pola asuh authoritarian, permissive, dan uninvolved. Selanjutnya, Setyaningrum, Yulianti dan Asra (2020) juga menemukan bahwa remaja dengan pola asuh authoritative akan mampu untuk menunjukkan perilaku asertif, hasil ini menunjukkan bahwa pola asuh authoritative merupakan salah satu faktor yang mempengaruhi perilaku asertif pada remaja Minang, karena dalam pengasuhan authoritative orang tua memberikan kesempatan kepada anak untuk terbuka dalam menyampaikan keinginannya sehingga akan terbentuk kepercayaan diri pada remaja dalam mengutarakan pikiran dan pendapatnya pada lingkungan sosialnya. Hal ini juga didukung oleh penelitian Ellis (2007) menemukan bahwa anak-anak dari gaya pengasuhan otoritatif ditemukan lebih asertif, aktif, mandiri, pro-sosial, berorientasi pada pencapaian daripada anak-anak dari orang tua permisif mendapat nilai terendah pada ukuran asertivitas, kontrol diri, dan kompetensi.

Sejalan dengan hal tersebut, Maccoby (dalam Gota, 2012) menjelaskan bahwa pola asuh authoritative lebih efektif dari ketiga pola asuh yang lain dalam membentuk kepribadian anak, karena dalam tipe pola asuh ini terjadinya komunikasi dua arah, serta anak berpartisipasi dalam pengambilan keputusan dalam keluarga. Anak dengan pola asuh authoritative menunjukkan perkembangan emosional, sosial dan kognitif yang positif, anak akan menampilkan perilaku yang ramah, asertif, kepercayaan diri yang tinggi, dan mampu untuk mengatasi stres dengan baik. Selanjutnya, subjek dengan pola asuh permissive memperoleh nilai mean asertivitas tertinggi kedua setelah pola asuh authoritative yaitu 73,13. Hal ini sesuai dengan penelitian Alayi, Khamen, Ahmadigatab (2011) yang menemukan bahwa individu dengan pola asuh permissive memiliki asertivitas lebih tinggi dari pola asuh authoritarian.

Subjek dengan pola asuh authoritarian memperoleh nilai mean yang paling rendah, yaitu 37, 10. Hal ini menunjukkan bahwa subjek dengan pola asuh authoritarian memiliki asertivitas paling rendah. Mengacu pada Baumrind, Maccoby, dan Martin (dalam Gota, 2012) orang tua dengan pola asuh authoritarian membatasi kebebasan anak-anak mereka, memaksakan anak untuk mengikuti aturan tanpa diskusi terlebih dahulu, dan menggunakan hukuman bila aturan dilanggar. Jika anak dihukum setiap ingin memberikan suara dan ingin mengatakan tidak, ia akan menarik diri, pasif, cenderung cemas dan penakut, ia akan belajar bahwa baik untuk selalu tetap diam (Rathus \& Nevid, 1977). 
Jadi secara umum hasil penelitian ini mendukung hasil penelitian sebelumnya oleh Marini dan Andriani (2005) serta penelitian Khalisah dan Lubis (2016) yang menemukan bahwa diantara keempat jenis pola asuh orang tua memiliki hubungan signifikan yang berbeda dengan asertivitas pada remaja. Namun, ditemukan sedikit perbedaan pada penelitian sebelumnya subjek dengan pola asuh neglectful memperoleh asertivitas yang paling rendah dibandingkan ketiga pola asuh lainnya tetapi dalam penelitian ini subjek dengan pola asuh authoritarian yang memperoleh asertivitas yang paling rendah dibandingan ketiga pola asuh lainnya. Dalam penelitian ini, subjek dengan pola asuh authoritative memperoleh nilai asertivitas yang paling tinggi, kemudian subjek dengan pola asuh permissive memperoleh nilai asertivitas lebih rendah dari pola asuh authoritative, subjek dengan pola asuh neglectful memperoleh nilai lebih rendah dari pola asuh authoritative dan permissive. Kemudian, subjek dengan pola asuh authoritarian memperoleh asertivitas yang paling rendah dibandingkan ketiga pola asuh lainnya.

Berdasarkan analisis data tambahan yang diperoleh dalam penelitian ini diketahui bahwa tidak terdapat perbedaan asertivitas antara laki-laki dan perempuan. Hal ini juga sesuai dengan penelitian Hasnabuana dan Sawitri (2015) serta penelitian Parray dan Kumar (2017) yang juga menemukan bahwa tidak terdapat perbedaan asertivitas yang signifikan antara laki-laki dan perempuan. Hal ini berarti menunjukkan bahwa laki-laki dan perempuan memiliki taraf yang sama berkaitan dengan asertivitas.

\section{Kesimpulan}

Berdasarkan hasil penelitian ini diperoleh kesimpulan bahwa pada umumnya asertivitas remaja Minang berada pada kategori sedang. Kemudian, dalam penelitian ini juga diperoleh hasil bahwa terdapat perbedaan yang signifikan dalam asertivitas ditinjau dari pola asuh orang tua. Selanjutnya, dalam penelitian ini juga ditemukan bahwa tidak terdapat perbedaan yang signifikan dalam asertivitas antara laki-laki dan perempuan.

\section{Saran}

Asertivitas merupakan hal yang penting yang perlu diterapkan dalam kehidupan sehari-hari, hal ini akan memberikan dampak positif kepada diri individu. Oleh karena itu, sangat penting bagi individu untuk meningkatkan perilaku asertif. Hal ini juga tidak terlepas dari pengaruh pengasuhan orang tua. Seperti yang diketahui, orang tua memiliki peran penting dalam perkembangan asertivitas.

Bagi orang tua, diharapkan penelitian ini dapat menjadi bahan rekomendasi untuk penerapan gaya pengasuhan yang tepat dalam meningkatkan kemampuan asertivitas anak. Kemudian untuk penelitian selanjutnya, peneliti dapat menambahkan etnis lain sebagai pembanding asertivitas dan gaya pengasuhan antar etnis untuk memperkaya hasil penelitian ini. 


\section{Daftar Pustaka}

Alberti, R., \& Emmons, M. (2017). Your perfect right: assertiveness and equality in your life and relationships. Oakland: New Harbinger Publications.

Abdulkarim, A., Zainul, A., \& Maryani, E. (2014). Perilaku asertif dan kecenderungan kenakalan remaja berdasarkan pola asuh dan peran media massa. Jurnal Psikologi, 41(1), 74-88.

Andayani, F. T., \& Mardianto. (2015). Perbedaan asertivitas antara mahasiswa etnis minang dan etnis batak. RAP UNP, 6, 33-44.

Azwar, S. (2012).Pengukuran skala psikologi. Yogyakarta: Gava Media.

Alayi, Zahra., Khamen, Z., \& Ahmadigatab, T. (2011). Parenting style and self-assertiveness : effects of a training program on self-assertiveness of Iranian high school girls. Procedia Social and Behavioral Sciences, 30. https://doi.org/10.1016/j.sbspro.2011.10.378

Bkkbn. (2017). Kepala Bkkbn ajak remaja menjadi generasi berencana. https://www.bkkbn.go.id/detailpost/kepala-bkkbn-ajak-remaja-menjadi-generasi-berencana.

Dagnew, A., \& Asrat, A. (2017). The role of parenting style and gender on assertiveness among undergraduate students in Bahir Dar University. Saudi Journal of Humanities and Social Sciences, 2(3), 223-229. https://doi.org/10.21276/sjhss.2017.2.3.4

Dahlan, Sopiyuddin. (2014). Statistik untuk kedokteran dan kesehatan (Edisi 6). Jakarta: Epidemiologi Indonesia

Delavita, N. (2019). Perbedaan perilaku seksual ditinjau dari pola asuh pada remaja yang berpacaran (Skripsi tidak diterbitkan). Universitas Negeri Padang, Padang.

Ellis, R. (2007). Relationship between parenting styles and children motivational style: The development of learned helpless. Unpublished master's thesis. Wichita state: Faculty of Education, Wichita state University.

Eslami, A. A., Rabiei, L., Afzali, S. M., \& Hamidizadeh, S. (2016). The effectiveness of assertiveness training on the levels of stress, anxiety, and depression of high school students. Iranian Red Crescent Medical Journal, 18(1), 1-10. https://doi.org/10.5812/ircmj.21096

Fajri, N., Nirwana, H., \& Alizamar, A. (2019). Assertive behavior of Minangkabau and Batak implications in development services social capability. Journal of Educational and Learning Studies, 2(1), 1. https://doi.org/10.32698/0332

Firdaus, D. R. S., P.Lubis, D., Susanto, D., \& Soetarto, E. (2018). Potret Budaya Masyarakat Minangkabau berdasarkan keenam dimensi budaya Hofstede. Sodality: Jurnal Sosiologi Pedesaan, 6(2). https://doi.org/10.22500/sodality.v6i2.23229 
Fitrianto, Heri. (2012). Pola komunikasi dalam keluarga etnis Minangkabau di Perantauan dalam membentuk kemandirian anak. Universitas Gunadarma: Depok.

Gota, A. A. (2012). Effect of parenting styles, academic self-efficacy, and achievment motivation on the academic achievement of university students in Ethiopia. 315-316. https://doi.org/10.1057/9781-349-95943-3_324

Handayani, N. (2015). Perbedaan Kontrol diri dalam Berkendara pada remaja dibawah umur ditinjau dari pola Asuh orangtua (Skripsi tidak diterbitkan). Universitas Negeri Padang, Padang.

Hasnabuana, Y., \& Sawitri, D. R. (2015). Asertivitas ditinjau dari kemandirian dan jenis kelamin pada remaja awal di SMPN 1 Smarang. Empati, 4(April), 219-223.

Hosseini, S. A., Mirnasab, M. M., Salimy, H., \& Zangiabadi, M. (2015). The effect of assertiveness skills training on reduction of emotional victimization of female high school students. International Journal of Life Sciences, 4, 59-64.

Hurlock, E. B. (1993) Psikologi Perkembangan Suatu Pendekatan Sepanjang Rentang Kehidupan. Jakarta: Erlangga.

Khalisah, S., \& Lubis, R. (2016). Perbedaan perilaku asertif ditinjau dari pola asuh orang tua pada remaja yang memiliki clique. Jurnal Diversita, 2, No.1, 10-22.

Lee, J. yeon, \& Ciftci, A. (2014). Asian international students' socio-cultural adaptation: Influence of multicultural personality, assertiveness, academic self-efficacy, and social support. International Journal of Intercultural Relations, 38(1), 97-105. https://doi.org/10.1016/j.ijintrel.2013.08.009

Marini, L., \& Andriani, E. (2005). Perbedaan asertivitas remaja ditinjau dari pola asuh orang tua. Psikologia, I(2), 46-53.

Mohebi, S., Sharifirad, G. H. R., Shahsiah, M., Botlani, S., Matlabi, M., \& Rezaeian, M. (2012). The effect of assertiveness training on student's academic anxiety. Original Article, 62(March).

Oktaria, A., Siregar, A., \& Kustanti, E. R. (2018). Hubungan antara gegar budaya dengan penyesuaian diri pada mahasiswa bersuku Minang di Universitas Diponegoro. Jurnal Empati, 7(April), 48-65.

Parray, W. M., \& Kumar, S. (2017). Assertiveness among Undergraduate Students of the University. The International Journal of Indian Psychology, 4(1), 76.

Pratama, A. (2019). Nilai-nilai pendidikan Islam dan pola asuh orang tua dalam falsafah hidup adat Minangkabau untuk melahirkan masyarakat yang tangguh di kota Payakumbuh, Sumatera Barat (Doctoral dissertation). Universitas Islam Indonesia : Yogyakarta. 
Pratiwi, W. E. (2015). Pengaruh budaya Jawa dan harga diri terhadap Asertivitas pada remaja siswa kelas X di SMA Negeri 3 Ponorogo. Jurnal Psikologi, 3(1), 348-357.

Rathus, S.A., \& Nevid, Jeffrey. (1977). Behaviour therapy strategies for solving problems in living. New York: Doubleday \& Company Inc.

Santrock, John W. (2014). Adolescence psychology. New York: Mc-Graw Hill Education.

Setyaningrum, R. B., Yulianti, A., Asra, Y. K., Psikologi, F., Islam, U., Sultan, N., \& Kasim, S. (2020). Pola asuh authoritative dengan perilaku asertif remaja keturunan minang di SMA Negeri 11 Pekanbaru. Psikobuletin: Buletin Ilmiah Psikologi, 1(2), 101-109

Shilling, C. S. (2007). The relationship between the assertive behavior of parents and the behavior of their children. The American Journal of Family Therapy, January 2015, 37-41. https://doi.org/10.1080/01926187908250328

Steinberg, L., \& Morris, A. S. (2001). Adolescent development. Annual Reviews Psychology, 83-110.

Suciati, R., \& Agung, I. M. (2017). Perbedaan ekspresi emosi pada orang Batak, Jawa, Melayu dan Minangkabau. Jurnal Psikologi, 12(2), 99. https://doi.org/10.24014/jp.v12i2.3236

Sudha, R. (2005). How to be an assertive nurse?. Nursing journal of India, 96(8), 182. 